\title{
KIF5B/RET Fusion Protein
}

National Cancer Institute

\section{Source}

National Cancer Institute. KIF5B/RET Fusion Protein. NCI Thesaurus. Code C114800.

A fusion protein encoded by the KIF5B/RET fusion gene. This protein is comprised of the motor domain and various portions the coiled-coil domain of the kinesin-1 heavy chain protein, fused with the C-terminal cytoplasmic domain of the proto-oncogene tyrosineprotein kinase receptor Ret protein, including the tyrosine kinase domain. 